\title{
A CONSTITUIÇÃO DA ESTÉTICA DOCENTE CONTEMPORÂNEA: DIÁLOGOS SUBJETIVOS
}

\author{
THE CONSTITUTION OF CONTEMPORARY TEACHING \\ AESTHETIC: SUBJECTIVE DIALOGUES
}

LA CONSTITUCIÓN DE LA ESTÉTICA DOCENTE CONTEMPORÁNEA: DIÁLOGOS SUBJETIVOS

\author{
Juliana Monteiro Vieira \\ Universidade Federal de Sergipe (PPGED/UFS) \\ Cristiano Ferronato \\ Universidade Tiradentes (UNIT-SE) \\ Dinamara Garcia Feldens \\ Universidade Federal de Sergipe (PPGED/UFS)
}

Resumo Buscamos refletir neste texto acerca da constituição estética da docência contemporânea, evidenciando suas perspectivas macro e microestruturais. Perpassando o diálogo com três docentes do município de Aracaju/SE, propomos analisar seus discursos por meio do auxílio teórico do filósofo alemão Friedrich Nietzsche e das linhas cartográficas de Gilles Deleuze e Félix Guattari. Evidenciam-se nesses diálogos os movimentos de atividade e passividade que constituem a vivência e o cotidiano da docência, buscando-se traçar o mapa de travessias que fundamentam a atividade. Do campo estável, finito e endurecido da macroestética docente surge a produção singular que desestabiliza e movimenta o fazer cotidiano, configurando o processo de "tornar-se professor".

Palavras-chave: Docência; Estética; Subjetividade.

Abstract We seek to reflect in this text about the aesthetic constitution of contemporary teaching, evidencing its macro and microstructural perspectives. Through the dialogue with three teachers from the city of Aracaju/SE, we propose to analyze their discourses through the theoretical help of the German philosopher Friedrich Nietzsche and the cartographic lines of Gilles Deleuze and Felix Guattari. These dialogues show the movements of activity 
and passivity that constitute the daily experience of teaching, seeking to trace the map of crossings that ground the activity. From the stable, finite and hardened field of the macroesthetics teacher emerges the singular production that destabilizes and moves the daily doing, configuring the process of "becoming a teacher".

Key-words: Teaching; Aesthetics; Subjectivity.

Resumen Buscamos reflexionar en este texto acerca de la constitución estética de la docencia contemporânea, evidenciando sus perspectivas macro y microestructurales. Al pasar el diálogo con tres docentes del municipio de Aracaju/SE, proponemos analizar sus discursos a través del auxilio teórico del filósofo alemán Friedrich Nietzsche y de las líneas cartográficas de Gilles Deleuze y Félix Guattari. Se evidencian en estos diálogos los movimientos de actividad y pasividad que constituyen la vivencia y cotidiano de la docencia, buscando trazar el mapa de travesías que fundamentan la actividad. En el campo estable, finito y endurecido de la macroestética docente surge la producción singular que desestabiliza y mueve el hacer cotidiano, configurando el proceso de "convertirse en profesor".

Palabras clave: Docencia; Estética; Subjetividad.

\section{INTRODUÇão}

Propõe-se neste texto dialogar com três professoras do município de Aracaju/SE acerca da constituição da estética docente contemporânea. Marina, Inês e Luana nos auxiliam a pensar as linhas de forças ativas e passivas que perpassam o cotidiano dessa profissão. Por meio da reflexão teórica das obras e conceitos de Friedrich Nietzsche (1844-1900) e do auxílio das linhas cartográficas de Gilles Deleuze (1925-1995) e Félix Guattari (1930-1992), construímos caminhos para adentrar aspectos simbólicos e práticos da vivência docente, compreendendo a trajetória singular de nossas personagens. As pulsações trazidas por elas durante as entrevistas ampliaram as possibilidades de entendimento ou interpretação de seus discursos. Buscamos, neste contexto, traçar linhas cartográficas que se movimentam nos discursos.

Traçar linhas é, então, constituir outros pontos de vista sobre o conjunto de uma dada situação: "O que é, no fundo, uma linha? É um signo que engloba o tempo, o elemento de base de uma semiótica da duração" (ZOURABICHVILI, 2004, p. 32). Não há, pois, como fazer uma análise automática das ações práticas ou discursivas, mas sim, pensar um processo de territorialização e (des)territorialização contínuo. O território é pensado aqui a partir do “domínio do ter". Esse domínio também pressupõe vias de deslocamento, de saída: não há território sem saída. A territorialização só ocorre porque ocorre a (des)territorialização; só é território-fixo para ser território-fluxo novamente (DELEUZE; GUATTARI, 1996). Percebeu-se também a impossibilidade de trabalhar com as linhas como estratificações endurecidas, enquanto traçados definidos, já que delas só teremos os efeitos, os rastros 
e as marcas. Pretendemos pensar as linhas como forças em um plano subjetivo movente, imanente, esteticamente figurados junto às três transmutações do espírito de Nietzsche em "Assim falou Zaratustra" (2011): molar (camelo), molecular (leão) e fuga (criança).

Inicialmente, os discursos versam sobre a produção molar, endurecida, hierárquica da docência. Uma macroestética configurada por agentes passivos e dominados diante de uma lógica construída durante a história do Ocidente. Alguns aspectos são perpassados: trajetórias, gênero (vida pública - vida privada), estereótipos da docência. A "maquinaria escolar" vai deixando seus rastros: valores religiosos que ainda predominam, a ética utilitarista, onde priorizam-se o aperfeiçoamento e o acesso ao mercado e promove uma serialização e uma produção massiva de sujeitos técnicos. As violências e fardos da experiência docente vão se descortinando nos discursos, evidenciando uma crise da autoridade docente e os afetos despotentes que compõem esse cotidiano.

É inegável, porém, a produção constante de deslocamentos das lógicas estabelecidas, reforçadas a todo o momento por contraposições nos discursos das entrevistadas. Então, ao mesmo tempo em que estabeleciam as "finitudes" dos modelos empregados, também associavam suas experiências às suas vidas, a movimentos subjetivos de singularização. $\mathrm{O}$ "tornar-se professor" configura-se como uma espécie de microestética, uma docência que habita o sujeito, uma produção singular de novas lógicas e novas posturas existenciais. $\mathrm{O}$ estabelecimento do "finito-ilimitado" pode ser considerado a partir dessas perspectivas macro e microestéticas: um campo molar, duro, estável, que se desestabiliza e se movimenta na produção singular do seu fazer cotidiano.

\section{As LINHAS CARTOGRÁFICAS E ESTÉTICAS DA DOCÊNCIA}

A cartografia é discutida e formulada pelos pensadores franceses Gilles Deleuze e Félix Guattari, conceituando-a na introdução de "Mil Platôs" (1996), em contraposição aos métodos tradicionais que dissociam o sujeito e o objeto. Surge junto aos questionamentos acerca dos regimes de administração da verdade onde demonstravam uma espécie de "ceticismo sistemático" e se utilizavam da desconstrução da constituição social da realidade. A cartografia se fundamenta na imanência, na medida em que percebe que tudo se realiza pelo meio e não por sua origem ou por seu fim. Esse meio é o meio do acontecimento, que logo se confunde com o meio da existência. Por intermédio da cartografia, é possível desconstruir os mitos da neutralidade e da objetividade científica, pressupostos valorativos que correspondem a ideais racionalistas próprios. Os problemas são, então, epistemológicos e não apenas metodológicos. Inscrita principalmente em uma perspectiva de análise institucional, a cartografia propõe a análise das linhas e estratificações profundas e superficiais dos objetos em questão, os micro e macrocontextos da natureza da pesquisa.

As linhas moleculares, descritas na cartografia, se dão como produções desviantes que inauguram outras formas de institucionalidade por meio da ressignificação, tendo relativo "controle" do acontecimento. Os níveis moleculares se dão nos movimentos de questionamento dos fardos, nas minorias desviantes, nas ações que não recorrem aos procedimentos 
e técnicas alienantes e redutores, usualmente utilizados como resolução das questões. As práticas moleculares ou microfísicas são aquelas que se instauram de modo mais sutil, rarefeito, delgado, atualizando os espaços subjetivos como segmentaridades mais flexíveis. As linhas moleculares adquirem um estatuto ambíguo, na medida em que uma prática desviante pode permanecer ainda prisioneira de concepções redutoras do mesmo campo dominante.

Os indicadores molares sinalizam estados de cristalização e padrões instituídos, de fatores e práticas identitárias. Fardos inflexíveis, típicos das cargas que os camelos carregam nas costas. Tudo o que foi molecular tende a tornar-se molar devido à extensão que se dá como prática. A molaridade está naquilo que é habitual, conhecido, naquilo que já supõe um sujeito realizador, que já identifica nesse sujeito aquilo que se materializa. Nesse contexto, até um ato libertário, revolucionário, que fuja dos padrões, passa a ser molar quando se torna um hábito, algo que está sempre ali exercitando a mesma lógica. Nesse contexto, repito: não há como fazer uma análise automática das ações práticas ou discursivas, mas sim, pensar um processo de territorialização e (des)territorialização contínuo.

As linhas de fuga são vetores de desordem. Fugir é também perder a forma estável, sair da clausura, escapar. O susto da desorganização em uma situação bem arranjada, o impacto de fazer algo que ninguém espera vir de você, a não sujeição dos desejos aos recortes identitários preestabelecidos... da fuga só se sentem os efeitos. Os devires que perpassam essa linha relacionam-se privilegiadamente com a infância, com o espírito da criança que se esquiva das dicotomias e binaridades. São linhas mais raras e difíceis de se localizar no mapa, pois se instauram enquanto transmutação, criação de novos valores e de novos fluxos.

Existe na cartografia a necessidade de se opor às operações reducionistas e binarizantes, considerando que as linhas de força estão em constante cruzamento e transformação. Pensamos aqui a subjetividade não enquanto "consciente-inconsciente", mas composta de estratos heterogêneos e múltiplos que constantemente rompem com os sentidos, em busca de singularização. Heterogêneos, sob o ponto de vista da constituição de múltiplos universos de referência, novas composições ontológicas sem a validação de uma substância única. Não se trata de definir a partir das falas o que são práticas molares, moleculares ou de fuga e sim, tentar compreender nos discursos proferidos como esse movimento incessante tende a se realizar.

A subjetividade produz-se a partir das instâncias individuais e coletivas, podendo esses movimentos subjetivadores constituírem-se enquanto valores emancipatórios ou não. O que move, nessa perspectiva, são as forças contidas no sujeito e não na metafísica ou na transcendência. Demonstra-se falida, portanto, uma representação universalista da identidade subjetiva, o que evoca a necessidade de invenção de novos universos de referência.

\section{A MaCroestética da doCÊnCIA: PASSIVIDAde E DOMINAÇÃo}

O principal interesse é construir as ideias que partilhamos a partir das falas docentes e de seus movimentos, considerando a palavra uma contribuição, um índice em meio ao fluxo processual. Os destaques em negrito nas falas diretas irão apontar os grifos que julga- 
mos importantes para contextualizar as discussões propostas. Compreender a constituição da estética contemporânea não permite aprisionar apenas em palavras o que pode estar no não-dito, no contrário, no corpo, nos sentidos ou na falta deles. Nessa perspectiva, afirma-se a coabitação de linhas de força ativa e reativa em cada professor, sendo importante compreender como esses arranjos e engendramentos funcionam. Interessa-nos, portanto, não falar dos discursos, mas das linhas que compõem os discursos. Discursos esses pertencentes a subjetividades culturalmente produzidas - a fala é linhas.

As trajetórias de Inês, Luana e Marina proporcionam essa interação. Cada uma de sua forma, em seu plano de experiência, (re)formulou-se junto à produção de sua docência, deixando marcas e vestígios das linhas que percorreram e que, cotidianamente, percorrem.

"[...] para a escolha pelo curso de Pedagogia foi considerada a questão da facilidade no ingresso à Universidade, devido a estar 18 anos sem estudar e pela questão da idade 'pra' entrar no mercado de trabalho e oportunidade também de trabalho. Então, foram considerados esses pontos para que eu escolhesse fazer Pedagogia. Eu atuava em uma área totalmente diferente, atuava com marketing, com vendas e foi num momento difícil em que eu precisava buscar alternativas" (Inês, 53 anos de idade, 2016).

"Minha trajetória enquanto docente começou bem antes da faculdade, né. Tudo começou quando eu, antes mesmo...meu ensino médio já foi na área de habilitação do Magistério, só que antes de fazer o ensino médio eu já dava aula. Porque assim, eu morei sempre no interior e lá no interior não precisava né, de formação específica [...] 'pra' você dar aula. Então, se você tinha o perfil, se você tinha habilidade, se a comunidade reconhecia que você tinha essa capacidade, já começava..." (Luana, 37 anos de idade, 2016).

“[...] Primeiro eu entrei na faculdade cursando História, [...] eu tinha 18 anos. Já perto de terminar, faltando algumas matérias, eu resolvi parar. Passei a atuar no campo da música né, porque eu tinha formação técnica de Conservatório e tocava, e acabei praticando a docência nessa área. Acho que o meu chamado 'pra' docência ele veio sim através da música...a música que foi o meu chamado" (Marina, 51 anos de idade, 2016).

Inês, 53 anos de idade, formada em Pedagogia há 10 anos, relata que a escolha do curso foi feita de forma prática, na busca de alternativas que poderiam corresponder às expectativas do mercado e às suas necessidades individuais. As linhas molares que tracejam seu discurso perpassam os compartimentos fechados da idade, do gênero, do mercado de trabalho, das alternativas econômicas etc. Seu envolvimento ativo com projetos sociais para jovens em situação de vulnerabilidade e seu trabalho com a EJA fazem de sua atuação em diversos âmbitos e públicos e sua formação relativamente tardia algo interessante de aqui visualizarmos.

Para Luana, 37 anos de idade, a docência foi algo percebido por ela e por outros como uma opção primordial, como algo reconhecidamente seu: um perfil que já possuía as "atribuições imaginadas" para uma professora. Essas atribuições confluem no imaginário 
popular acerca da docência e costumam influenciar as expectativas internas e externas, no que tange às funções e características da profissão: vocação, maternagem, profetização, cuidado, instrução, entre outros. Luana, nascida e criada no interior do Estado de Sergipe, estudante da área rural durante boa parte de sua vida, recém-contratada como professora universitária. O desconforto e criticidade com relação à sua nova posição, suas desconstruções, seu saudosismo da vida rural atraem a atenção para os seus questionamentos.

Já Marina, 51 anos de idade, obteve na música sua primeira experiência em aula; o "chamado" da música foi também o chamado da docência. Sua trajetória é recheada de pessoas-referências, rupturas, descontinuidades que compõem com os acontecimentos de sua canção-vida singular. O contato com seus desempenhos, por sua atuação com crianças, a sua interação com comunidades e tecnologias sociais e a sua experiência com teorias "alternativas" na área da educação fizeram dela a terceira voz desse diálogo.

A questão de gênero não foi uma referência apriorística, nem de busca nem de análise. Porém, ao longo do caminho, fomos nos deparando com o importante questionamento: como não falar de gênero ao falar de docência? Os temas parecem estar intrinsecamente ligados por sua história e por seus fundamentos. Como parte das andanças, os contatos que nos levaram a essas mulheres pareciam caminhos tracejados que se realizavam enquanto se faziam, construindo-se nos atravessamentos.

A distinta configuração entre "vida pública - vida privada" é traçada no Ocidente desde os gregos, quando tornam a pólis um ideal de universo público e reafirmam a distinção entre as esferas da família e da política. Anterior às sociedades modernas, a constituição dos signos da docência perpassa um sentido primário, primitivo, de foro íntimo, em consonância à ideia de "fazer virar adulto, de civilizar". A docência encontra-se em um âmbito de efetivação e disseminação das políticas sociais, sendo o principal objetivo do professor "modificar" o aluno, transformá-lo em algo que ainda não é, em uma versão melhorada de si mesmo (um processo de "melhoramento"). À mulher, parte integradora do sistema de signos privados e domésticos, é atribuído o compromisso social de cuidar, de ensinar as coisas certas e erradas à sua prole, de lidar com as demandas do lar, da fé e da moral, sob uma condição submissa.

No Brasil, os jesuítas foram os primeiros a se ocupar da formação de meninos brancos e de famílias nobres. Ao final do século XIX, durante o processo de urbanização do país e ressignificação da educação, as mulheres recebem "concessões" para se deslocarem do âmbito privado para o público carregando, porém, os signos incorporados às suas funções sociais: procriar, cuidar, ensinar. Apoiadas na educação como destino do progresso nacional, as obrigações femininas estariam ligadas à educação da infância e à formação de bons cidadãos (filhos e alunos) que cumpram com os interesses da nação e com seu desenvolvimento para então, "construir uma imagem do país que afastasse seu caráter marcadamente colonial, atrasado, inculto e primitivo" (LOURO, 2008, p. 443).

A ideia de progresso parece estar intimamente ligada a uma postura de "homem mais governável" e a educação moral atrelada a um "agir melhor". Durante o regime militar brasileiro, compreendido entre os anos de 1964 a 1985, se reforçam as concepções de gênero 
previamente estabelecidas trazendo no modelo tecnicista claras diferenciações entre as atribuições femininas e masculinas. A intervenção do Estado na escola e na profissão docente provocou uma espécie de homogeneização dos comportamentos conservando, porém, as referências sacerdotais da imagem do professor do século XIX. Mesmo sendo considerados "funcionários do Estado", necessitavam estar presentes nesse sujeito docente virtudes cristãs como a humildade, a doação e a obediência à autoridade. Com as crianças - seres selvagens, não possuidores de saberes, indivíduos a serem moldados e transformados - eram compartilhadas essas ideias de "virtude", legitimando e disseminando esses símbolos morais.

"[...] a gente tem que dar aula que nem Xuxa, chamando atenção! (risos) Ás vezes, quando você fala "Ah, as crianças não estão interessadas..."; a coordenação fala: "Mulher, faça alguma coisa..."; É tipo: se vista de palhaça, faça alguma coisa!! [...] você tem que domar aquela agitação da criança que não quer aquele assunto, né? Quer um assunto novo...” (Marina, 2016).

Marina parece precisar elaborar estratégias para "domar" os instintos selvagens que há pouco referimos, já que atua com crianças no ensino fundamental. As sensações descritas por ela parecem comuns à vivência de vários colegas, no que tange, principalmente, à necessidade de dominação, engessamento, contenção de toda a energia, agitação e efervescência infantil. Vestir-se de palhaça, de apresentadora, fazer alguma coisa! O docente precisa elaborar estratégias que sirvam aos interesses institucionais, sem por isso modificar os conteúdos previamente deliberados dos quais claramente as crianças não demonstram interesse, pois, claro, querem algo novo!

Configuramos preconcepções que referem o professor enquanto sujeito-profeta, pois o mesmo é possuidor de uma "altiva sabedoria", é quem realiza o anúncio do certo e do errado, dos modos de fazer, das leis e das direções. A figura do "mestre" pressupõe o agente prático que auxilia a reduzir a distância entre a ignorância e o saber. O professor-profeta compõe-se seguindo diretrizes de uma "educação maior", dos planos molares, decenais e das políticas públicas, dos conhecimentos produzidos a partir de uma esfera macropolítica; é na verdade, o carregador de fardos, o professor-camelo (GALLO, 2002).

A escola referendou e referenda na contemporaneidade o espaço de hierarquização, subordinação e subalternidade de gênero assumido por seus idealizadores. A pretensão moderna de edificar um povo ordeiro e civilizado reproduz também na escola uma hierarquia doméstica. Para a realização desse objetivo, foi necessário construir um "corpo de especialistas", sob um conjunto de normas e preceitos implícitos e explícitos, imbuídos à profissão docente que correspondem à história das caracterizações fabricadas no processo político e social.

"O meu aluno [...] tem muita dificuldade de quebrar paradigmas religiosos, tradicionais. O meu aluno tem muita dificuldade de pensar para além de uma formação criacionista, 'tá' entendendo? E isso é muito resultado da sociedade [...] porque o mundo 'tá' assim, né. Sei lá, Brasil, a comunidade, Aracaju, né. O povo só quer saber de Igreja [...] de um mundo muito fundamentalista [...] porque o meu aluno 'tá' assim e a escola também 'tá' assim. Porque se só fosse 
o aluno....a escola, a ambiência, né, o espaço ia 'pro' outro caminho e o aluno vinha...então, a gente se encontrava e tentava dialogar, mas não...só não 'tá' assim o professor. O aluno e a escola estão nesses caminhos aí, né? Do tradicional, do religioso, do moral e aquilo vai tomando conta da sala de aula" (Luana, 2016).

“[...] tem muitas professoras evangélicas, por exemplo, em época de consciência negra, né, tinham umas oficinas lá na escola, de turbantes. Aí teve uma professora que fez: 'olhe, eu só não aceito que venham falar da música da África porque é uma religião que não seria interessante para os meninos. Então, tragam tudo menos tambor'. Aí eu falei: 'mas porque menos tambor?"” (Marina, 2016).

Os valores religiosos, especificamente os valores judaico-cristãos, ainda se demonstram profundamente instaurados na escola brasileira, onde parecem crescer as tendências fundamentalistas e conservadoras que se remodelam a partir das novas prerrogativas. Luana fala sobre sua dificuldade diante de panoramas morais que parecem se expandir de forma intrínseca às instituições sociais, no olhar dos mais novos e dos mais velhos, no olhar não só da comunidade, mas da cidade, do país, do mundo. Já Marina, vê presente também nos docentes o cerceamento da crença boa e da crença má, da verdade divina e da mentira pecadora, dos batuques permitidos e dos batuques proibidos. A subserviência parece conviver com uma infinidade de preconceitos e compreensões deturpadas de outros sentidos ou de outros entendimentos individuais. Imbuídos de concepções que se camuflam como atributos, observamos cotidianamente o extremismo dos discursos demagógicos que muitas vezes também são transvestidos de discursos pedagógicos.

“[...] o indivíduo ele é do coletivo né, mas ele também tem que estar inserido ali. E é esse vai e vem...é o coletivo, mas é o indivíduo também [...]. É preciso valorizar essa singularidade, essa diferença mesmo de cada um ser cada um..." (Marina, 2016).

A gregaridade, tendência que leva os homens ou animais a se juntarem, foi edificada durante toda a história da humanidade e parece o fato mais decisivo e estruturante da mesma. Marina transporta para a sala de aula essa preocupação com a necessidade de valorizar as individualidades, sendo as ações pedagógicas quase sempre concentradas na totalidade, no coletivo, na produção de massa, de rebanho. A pretensa racionalidade desenvolvida pela educação moral permite apenas a identificação de padrões e a correção de condutas consideradas errôneas. Para Nietzsche (2011), mesmo estando em âmbito social, vivemos pouco a individualidade, a solidão, a corporeidade, em detrimento da substituição dos impulsos por padrões de comportamentos estabelecidos a priori. A adoção de valores alheios à própria experiência, sem compreender ou justificar essa escolha, nos torna um tanto "adormecidos" optando por vias mais cômodas e esperadas pela maioria.

Também parece importante apontar os pretensos ideais humanitários de "igualdade", seja do ensino ou mais amplamente, do comportamento, característica bem delineada pelo 
cristianismo e reafirmada pela Revolução Francesa, que termina por falsamente implicar uma sensação de universalidade, ideia considerada por Nietzsche um perigo para o pensamento da diferença. O bordão da "educação para todos" disseminado no Ocidente acaba por justificar um processo de massificação do sujeito, engendrado em uma espécie de aprisionamento simbólico que generaliza a ausência de ação sobre o mundo, dando-lhe "permissão" para um processo degenerativo de inatividade. Essa estagnação realiza-se frente à ideia do aluno como sujeito essencialmente receptor do conhecimento, consumidor do saber, aquele que não sabe previamente de nada, que nada tem a trocar com o professor.

\begin{abstract}
"Então, as vezes eu me vejo um pouco cansada nesse processo do ser professor, assim [...] porque o outro ele, até você extrair que ele sabe, porque ele se recusa a dizer que sabe, ele acha que o que ele sabe não é suficiente para aquele momento de discussão. Ele faz questão de se posicionar numa situação de inferioridade, de que: 'Eu não vou opinar porque eu não sei, professora" (Luana, 2016).
\end{abstract}

A maquinaria escolar sofreu transformações inúmeras e passou a ser vista enquanto uma das instâncias moduladoras e regulamentadoras da moral social. Essa estratégia de refinamento "da arte de governar" estabelece limites mais flexíveis conforme as intenções políticas vigentes e alimenta na contemporaneidade, modos de vida marcados pela incerteza, maleabilidade e instabilidade. Manteve-se, porém, o currículo engendrado pelas noções de ordem e representação.

“[...] olhe, muitos na mesma situação que eu, outros porque já estavam atuando na área e precisavam de diploma de nível superior, mas já eram professores atuantes. Mas assim, alguns relataram que não pretendiam atuar, pretendiam seguir outros caminhos. Por exemplo, tinha um policial na minha turma; [...] queria agregar valor, queria título para carreira dele. Então, tinha colegas que: 'ah, eu vou terminar e vou começar a fazer Direito, vou começar o que quero ainda'. Então, muitos que entraram na mesma condição que eu e poucos dispostos a continuar na área de Educação" (Inês, 2016).

“[...] porque eu já estava dando aula, eu já era professora, eu só queria uma habilitação né, queria uma certificação de que eu tinha capacidade 'pra' dar aula" (Luana, 2016).

"Ingressei no Mestrado porque já era uma própria exigência dos programas internacionais; [...] percebi que havia a necessidade de ampliar um pouco a minha formação [...] fiz o meu Mestrado um pouco afastada da sala de aula" (Luana, 2016).

"Iniciei a Pedagogia com 38 anos [...] foi em uma faculdade particular. Porque, tipo, eu já estava atuando e eu queria [...] o diploma, queria fazer uma coisa mais rápida" (Marina, 2016). 
O aperfeiçoamento das condições de acesso ao mercado de trabalho e a necessidade de qualificação diplomada foram assuntos que se fizeram presentes durante todas as entrevistas realizadas. $\mathrm{O}$ "formar-se" requer aqui certa desconstrução, pois se coloca não como processo que se dá na apreciação do saber, mas como instrumento de validação de uma atividade. O diploma na Modernidade encarna o valor da tradição: símbolo de status quo inquestionável. A ideia do aperfeiçoamento liga-se ao instinto de obediência, às necessidades de atender às demandas morais exteriores.

A condição de "eternos aprendizes" inscreve-se na docência e há certo tempo possui uma denominação específica - formação continuada. A problematização e a produção de discursos político-educacionais, principalmente ao longo do século XX, indicam as tendências emergentes relacionadas aos controles reguladores da formação de professores. A composição de certos elementos e práticas torna usual e naturalizada a proliferação discursiva dessa expressão, vista hoje como uma necessidade incontornável, como uma "saída milagrosa" para os problemas educacionais. A necessidade de nos tornar "sujeitos competitivos", capazes de abrir mão de sua nobreza ética, faz parte do amplo arcabouço da macroestética passiva. “Foi dessa desconstrução que eu senti falta, porque [...] na minha formação,
quando eu fui lá na prática que eu experimentei, eu não tinha 'pra' quem
contar porque o meu professor já não estava mais disposto a ouvir. Ele já
estava em outro período, com outro aluno discutindo novamente a mesma
teoria que ele tinha me passado. E aí eu: "Pera aí, professor, escuta aqui o que
eu tenho 'pra' lhe dizer. Olhe, não passe 'pro' seu aluno isso aí não, porque isso
ai ó, lá na Escola 'tá' falido". Só que o tempo não permite que você faça esse
exercício" (Luana, 2016).

“A gente vai atropelando os processos, a gente não para 'pra' escutar ou 'pra' fazer a síntese e a antítese, 'tá' entendendo? Então, eu acho que faltou isso na minha formação $e,[. .$.$] faltou isso no meu Mestrado e falta isso agora nos$ meus alunos que estão indo 'pra' sala de aula como professores, sabe?" (Luana, 2016).

A ideia de serialização, de produção massiva, de fabricação de "trabalhadores da educação", é explicitada nesse trecho por Luana, quando evoca os caminhos de sua formação. O lugar da "desconstrução" dos conteúdos e dos valores, de ir da afirmação à negação dos mesmos, desaparece na esteira de produção serial da "fábrica acadêmica" que não tensiona seus conteúdos a partir da prática dos alunos, que não os revisa, nem os relativiza. Essa "sensação de atropelo" descrita por ela parece evocar justamente a representação de um emparelhamento de conteúdos que pouco se aplicam na prática e podem converter-se em atitudes de revolta ou omissão. Esse modelo de formação, incerto e liquefeito, parece enunciar que cabe ao professor a responsabilidade de formular e reformular sua prática, desde que sempre em consonância com os ideais e teorias institucionais, em um processo contínuo de um "aperfeiçoamento de si". 


\begin{abstract}
"Eu tenho colegas que dizem assim 'vou ali vender uma aula', né...eu acho aquilo tão, tão forte assim...tão do ponto de vista do comercial, né [...] E aí a gente vai esbarrando nesses processos porque a Universidade nos cobra isso, a Universidade nos cobra mesmo a relação comercial, né, de cliente e o outro, que oferece o produto e esse produto tem que ser nota 10 , tem que trabalhar com competência né, que é um currículo hoje que me esvazia, porque ninguém consegue conceituar competência 'pra' mim [...] é uma ideia muito do marketing, do comércio, e que está se jogando para a educação e que a gente está comprando..." (Luana, 2016).
\end{abstract}

A interpretação da ética utilitarista utilizada como justificativa pelo sistema econômico vigente concede à educação sua parcela responsável pela disseminação e legitimação dos valores estabelecidos a favor do capital: competitividade, individualismo, egocentrismo, materialismo etc. $\mathrm{O}$ homem que persegue uma ascensão social na contemporaneidade tem a escola e a Universidade como os meios impulsionadores para atingir esses objetivos. A instrumentalização da educação para estar à disposição das operações do mercado acaba por suprimir as dimensões ético-estética e um possível diálogo com os conhecimentos adquiridos nesses locais.

O currículo por competência a que se refere Luana tem origem no ensino técnico da França sob a lógica capitalista de produção e significa, então, um currículo que responda às demandas de operacionalização frente ao mercado, que demonstrem a flexibilidade/ submissão do sujeito a partir das exigências do contratante, mão de obra rentável, que foque um conjunto de saberes técnicos, especializando e fragmentando o conhecimento científico. Essas segmentaridades molares são dispostas em normas padrões e universais de conduta que exigem resultados que condigam com os compromissos fixados por essa instituição desde sua fundação e radicalização na Modernidade.

Quando um professor vai "vender sua aula", ele vai corroborar e disseminar ideias do mercado escolar e da racionalidade econômica, há muito veiculadas no espaço social: tempo é dinheiro, conhecimento é objeto de troca, saberes são regimes de verdade, a ideia da meritocracia, entre outros. Essas são lógicas previsíveis de reação a um sistema econômico vigente, congeladas sob o modelo de eficiência esperado. Por serem lógicas passivas, não convidam as subjetividades a qualquer tipo de resistência, problematização ou questionamento.

Também parece necessário compreender e discutir o ambíguo papel exercido pelo professor e pela intervenção escolar na vida dos sujeitos perpassando a noção de violência. Toda força ou impulso exercido a partir de uma coação, sendo empregada de forma abusiva ou mesmo transformadora, é inevitavelmente, violenta. A organização do mundo se deu por um processo de violência, de choque entre forças que terminam por domesticar o homem e agredir os seus instintos. A ambivalência semântica dessa palavra nos permite pensar acerca da tensão exercida por forças antagônicas no espaço escolar, sendo a violência, na maioria dos casos, algo considerado exógeno à instituição escolar apesar de ser imanente a ela mesma - como uma força empregada que se mantém oculta.

A indigesta justaposição escola/violência é discutida por Groppa (1998) e compreendida como uma via de mão dupla constituída nos lugares que ocupam professor e aluno, 
sendo o exercício da autoridade, em si mesmo, o emprego de uma violência considerada "produtiva". Esse quantum de violência é gerado pelo teor normativo e pela dinâmica do confronto alimentada na escola, que busca homogeneizar corpos, comportamentos, gestos e atitudes. Essas prerrogativas coabitam a noção de um sujeito institucionalizado, consequência de reproduções difusas de outros contextos molares presentes em sua realidade: família, sociedade, política etc. A partir dos efeitos concretos da violência imanente à prática educacional forma-se um "pequeno campo de batalha civil" (p. 8) onde conflui um mal-estar e uma apatia coletiva.

"[...] nunca fui vítima de violência, nunca fui vítima de nada disso que eu vejo aparecer nos telejornais, 'tá' entendendo? As minhas violências enquanto professora eu sofri na sala dos professores ou em coordenações, sabe assim. As maiores violências [...] foram bem mais frequentes em uma Reitoria do que em uma sala de aula" (Luana, 2016).

Luana discorre sobre as violências sofridas durante sua experiência docente, não em esfera física, mas subjetiva. Violências que estão cotidianamente presentes em diversas formatações simbólicas. A concepção de memória nasce da necessidade de tornar o homem um animal previsível, um ser "confiável” à comunidade, estando diretamente ligado à obrigação de cumprir promessas, dar sua palavra, ter obediência pelas normas e valores morais. A forma espontânea de agir, onde havia espaço para o esquecimento, dá lugar à contenção dos instintos e impulsos que se voltam para dentro como força reativa, fluxo de impulsos na contramão do agir espontâneo dando origem ao ressentimento. O desenvolvimento da aptidão de "não esquecer" se demonstra também correlativo ao surgimento da má consciência.

Aos jovens, leões da realidade, movidos basicamente pela vontade, linhas de molecularidade efervescentes, estão empreendidas as maiores violências; a juventude é o principal alvo dos moralistas (NIETZSCHE, 2011). O processo de maturação é enfaticamente cobrado ao jovem, que segue questionando as raízes dos respectivos valores, porém, sentindo-se impelido a rapidamente tornar-se um adulto e se adequar ao pensamento vigente. É desses questionamentos e problematizações que surge o desconforto ao dialogar com os jovens.

“[...] as disciplinas, os conteúdos né, são enormes e muitas vezes não pertinentes aquele segmento, mas estão lá e o professor tem que seguir e tem que elaborar prova" (Inês, 2016).

"[...] é um desafio cotidiano assim, você é surpreendido a cada dia por interrogações, por questionamentos de alunos sobre essa 'verdade' que a gente tenta formular e apresentar ou até mesmo limitar 'pro' aluno, né. E você não está muito disposto, ás vezes, a discutir isso, né. Você quer passar o conteúdo porque é obrigatoriedade, porque 'tá' na grade, né, porque 'tá' no currículo, não quer que ninguém questione porque aquele questionamento vai fazer com que a aula não ande...” (Luana, 2016). 
O conhecimento científico, para Nietzsche (1998), é a grande paixão da Modernidade. O fato de conhecer livraria o homem de um suposto "retorno à barbárie original", como um antídoto civilizatório. A crítica ou pensamento autônomo do aluno são vistos como ameaça à produtividade e são desestimulados por sua independência em contestar os sentidos. $\mathrm{O}$ saber transforma-se em adestramento auxiliando na construção de um homem despotente e fraco. Essa perspectiva na escola circunda algumas referidas denominações, conforme tratam as docentes: disciplina, conteúdo, currículo. Obrigatoriedade.

"Passei a trabalhar com a cultura e $[\ldots]$ comunidades tradicionais, $[\ldots]$ um projeto $[\ldots]$ que durou seis anos. Tive contato com essa mata né, $[\ldots]$ mata de restinga, [...] na maioria mulheres, elas tinham uma vivência muito, muito forte com essa mata [...] e a gente era responsável por passar uma tecnologia de utilização do sol para beneficiamento. Quando a gente chegou lá, a gente viu um monte de coisa...nossa, quanto saber que tem ali, né? [...] e a gente ia 'pra' lá e mais do que dar algum conhecimento, a gente recebia muito mais" (Marina, 2016).

\footnotetext{
"No ano passado eu perguntei à turma [...] 'o que é que vocês querem ser quando crescer?' ah, eu quero ser costureira!, ah, eu quero ser médico e o outro, ah, eu quero ser advogado! Aí um menino: ah, eu quero ser um catador de massunin que nem a minha mãe!; aí a diretora chegou 'pra' mim, eu contando a história né, ela falou: 'Professora, mas sua obrigação é dizer o contrário. Você dizer a ele: 'aprenda a ler porque você vai ser um engenheiro'. Mas se ele quer dignamente seguir a profissão da mãe, o que é que tem? Então, as pessoas vão ter que ser todas advogadas e médicas e quem vai catar massunin? [...] porque isso é uma coisa da Educação, né...porque que eu vou transformar Davi em um engenheiro, se ele pode ser um homem de bem, catador de massunin? Porque não? E ganhar a vida dele...” (Marina, 2016).
}

Marina expõe, nos dois relatos, características que emergem do medo que a humanidade resguarda sobre aquilo que considera ser a "ignorância". Na primeira situação, a docente comenta acerca de seu trabalho em uma comunidade tradicional do interior do Estado de Sergipe, no qual foi contratada para disseminar conhecimentos sobre tecnologias sociais. No caminho, porém, descobriu uma infinidade de saberes que já havia ali, em sua maioria saberes práticos, do contato mulheres-mata, que nunca experimentara; "Não há ignorante que não saiba uma infinidade de coisas, e é sobre este saber, sobre esta capacidade em ato, que todo ensino deve se fundar" (RANCIÉRE, 2002, p. 11).

Na segunda situação, ficam claras as posições hierárquicas da escola, além de suas obrigações enquanto professora de disseminar um discurso moralizado que reafirma a concepção de que apenas por meio desse modelo de ensino, de ler e escrever, seria possível diminuir a "ignorância dos não-saberes" da mãe de Davi, catadora de massunin. A prática pedagógica é, portanto, apoiada nos pilares de oposição: ciência versus ignorância. Sob esse ponto de vista, não haveria qualquer tipo de conhecimento, relevância ou utilidade na 
atividade "não-científica", sendo o papel da escola preservar o desenvolvimento de habilidades para superar essa condição.

A "paixão pelo conhecimento" torna-se uma potência antagônica ao processo da educação e da aquisição de saberes, pois ao mesmo tempo em que indica força, é também aniquilamento da singularidade e da diferença. Não existe, para Nietzsche (2011), um conhecimento puro ou desinteressado já que tudo se encontra ligado ao homem ou à natureza enquanto construção e deliberação de sentido. Esse fenômeno torna-se ambíguo e complexo, tendo em vista o conhecimento enquanto uma interpretação, um valor, que se organiza junto aos limites da linguagem. Esses limites residem na simplificação da realidade, no empobrecimento da experiência para tornar compreensível um fato ao coletivo.

\begin{abstract}
"Culturalmente, o professor precisava romper com alguns paradigmas, sabe assim, daquela coisa do salvador, do querer se posicionar enquanto autoridade, de exigir o respeito, de estar num birô, de estar num púlpito, se não tiver o birô eu me sinto, 'tá' entendendo? Ameaçado..." (Luana, 2016).

“[...] e enquanto o professor quiser se posicionar como o 'todo poderoso', o sabido, o que vai levar...ele vai sempre esbarrar na ideia da incompletude mesmo..." (Luana, 2016).
\end{abstract}

A crise da autoridade docente parece nos remeter ao amplo espectro doente da escola e de sua macroestrutura social, na medida em que essa noção de autoridade (diga-se, obediência) é um dos pontos basais da estruturação institucional. O que acontece é que a escola também é esse lugar de derrocada dos valores e perdas de garantias, e o valor de "autoridade" é um desses que se esvaem. Basta pensar que a concepção de autoridade não estabelece como preocupação a formação ética do sujeito, mas sim o alcance de objetivos ligados à eficiência, à eficácia e à racionalidade instrumental. Essa "incompletude" referida por Luana e na qual esbarra o ser docente, está presente na ruína das certezas e na crise generalizada que reproduz uma espécie de "desautorização" de instâncias como a família e a escola. A educação é também o resultado do choque entre gerações, do embate narrativo de experiências dos mais velhos para os mais novos, gestos feitos para os que lhe sucedem (GROPPA, 1998).

“Eu fui vendo que essa relação de afeto que as crianças têm por você e você
por elas, é uma coisa que faz com que a aula signifique. [...] depois você vai
vendo que é, tipo mãe mesmo né... Quando falam 'ah, professora é uma
mãe...' essa coisa meio bucólica, mas de fato é [...] e a medida em que você
cria relação de afeto com essas crianças, é incrível, é como uma mágica, os
assuntos vão surgindo" (Marina, 2016).

Deparamos nessa fala de Marina com algumas problemáticas essenciais para a discussão do campo docente. $\mathrm{O}$ afeto na docência está diretamente ligado ao "gostar, ter carinho, amar as crianças, cuidar dos alunos", conforme explana de forma tão espontânea. Partindo 
dessa perspectiva, liga-se ao magistério uma espécie de "maternagem", onde se precisa cuidar, curar, ajudar: cargas que para o feminino já são muito molares, muito duras, muito pesadas. Essa experiência de "expansão da maternidade" obtém respaldo sob a justificativa de melhor habilitar a mulher ao ensino das classes iniciais, do ensino primário, devido à necessidade de criação de vínculos afetivos com as crianças (LOURO, 2008). Esses afetos, porém, constituem um modelo de sensibilidade que, para Nietzsche, são despotentes e fracos, pois nos iludem diante de uma superficial satisfação do espírito. Não há nesse modelo de docente, amor pela descoberta ou diálogo primordial com o conhecimento, mas paixões insólitas influenciadas diretamente pela construção cristã e moral vigente, pelo que é esperado do docente, por sua obrigação intrínseca de cuidar.

\footnotetext{
“[...] eu me identifiquei bastante com a base do curso que são as disciplinas de Política, Política 1 e Política 2, Filosofia, Sociologia, Filosofia da Educação e Sociologia da Educação; as disciplinas relacionadas a Psicologia do Desenvolvimento, da Aprendizagem, ainda fiz Psicologia Geral como optativa, Dinâmica de Grupo também como optativa [...] então, essa parte básica do curso fez com que eu me identificasse bastante e tivesse vontade de atuar propriamente na área" (Inês, 2016).
}

Podemos diferenciar nesse trecho da fala de Inês o que Nietzsche propõe como uma "nova concepção de afetividade", mais profunda que as paixões, pois evidencia um movimento, um impacto sofrido perante certo comportamento de estagnação. Inês utiliza palavras como identificação e vontade, indicações de mobilização de desejo, manifestações de uma segmentação mais maleável, mais molecular. Antes, ela via a docência apenas como uma necessidade prática: entrar em uma graduação para ter oportunidades no mercado de trabalho. Depois, houve uma captura, uma sedução pelo curso, uma produção real de vontade (de saber, de potência), um movimento ativo de conquista e fascinação. O deslocamento e o movimento subjetivo realizado em Inês produziu um arrebatamento, um engajamento, uma transformação.

Os afetos, para Nietzsche, são as mais violentas potências naturais e estão associados a uma expressão particular da vontade de poder, vinculados ao instinto e à pulsão. São sua forma mais primitiva e produzem modos de atração e repulsão. Aquilo que lhe atravessa nada tem a ver com carinho e sim com impacto, com impulso de transformação. Ao mover a vontade, o desejo produz singularidade: todo querer é uma força que se expressa e afirma a si mesmo a partir dessa expressão. Sendo força, tem o poder de conservar (quando é reativa) ou criar (quando é ativa). O desejo, portanto, é visto aqui como um plano movente, força mais potente entre outras forças, pois não há referência a uma instância exterior, transcendental ou "à falta de" algo, como reafirma a ideia de consciência construída pela cultura ocidental.

\section{A MiCROESTÉTICA DOCENTE: A CONSTRUÇ̃̃o dO TORNAR-SE PROFESSOR...}

Após pensar a estética docente sob um âmbito amplo, de esferas institucionalizadas, estratificações molares e endurecidas que tem bases em uma construção de valores espe- 
cífica e reverbera em um ideal de educação, nos pareceu fundamental também ilustrar as dissonâncias, os movimentos de ressignificação, de molecularização, fuga e diferenciação que claramente iam tomando corpo nas entrevistas. Depois de certas reflexões, consideramos a existência de algo que parecia uma microestética, uma dimensão singular, como movimentos de subjetivação realizados na produção individual da docência. O processo de "aprender a ensinar" parece coabitar soluções e resoluções próprias, posições de disponibilidade ou de abertura desinteressada que ilustram a diversidade de forças moventes nas práticas. Para além de serem apenas reféns das macroestruturas, essas docentes produzem para si mesmas novas lógicas e novas posturas existenciais.

“Então, como um professor marca mesmo a vida de um aluno [...] deixa
marcas e muitas vezes não percebe; porque eu acho que não se separa muito...
não separa o que você é enquanto pessoa, da sua prática. Eu me sinto muito
bem onde eu estou, sabe... Eu continuo sendo porque é uma coisa que me
identifica, mas só me identifica porque fica, 'tá' entendendo? Porque mar-
ca...." (Luana, 2016).

Associar docência e vida parece o único meio para fazer essa caminhada, na medida em que as potências ativas e reativas habitam nosso universo, compondo-o. É estando sempre entre essas duas forças que fabricamos a vida, parimos nossos atos, deixamos as nossas marcas. A docência habita o docente: suas verdades, mentiras, angústias e certezas. As marcas a que se referem, são marcas que identificam, são produções próprias em interação com esse campo de ação, como um procedimento puramente alquímico; "[...] o processo de formação de qualquer profissional deve passar, necessariamente, pela aprovação crítica de sua história de vida" (PEREIRA, 2013, p. 61).

$\mathrm{O}$ entendimento da microestética docente perpassa justamente o plano imanente que desfaz a distinção privado-público, na medida em que o que constitui o movimento de singularização da docência seja a produção dessa diferença na história do sujeito, uma escolha que se dá no mundo, elaborada em um campo coletivo. Não se trata, nessa perspectiva, da procura de uma essência ou de um perfil identitário, mas de um "tornar-se", em conjunto do que vinha sendo, dessa mesma descontinuidade, entre possível-finito e potencial-ilimitado (PEREIRA, 2013). Como separar sua prática de seus posicionamentos éticos, estéticos, políticos? De seus desejos, de suas experiências, de sua vontade?

São os movimentos realizados na contramão disso, em forma de ruptura ou deslocamento que pretendemos evidenciar neste breve item. A docência é, pois, esse lugar de estratificações rígidas e severas, porém, apenas durante o percurso individual se costura nas potências subjetivas.

\footnotetext{
"Então assim, essa dinâmica, o nosso jeito de fazer...e claro que aí eu entro naquela coisa: 'a Escola é possível? [...] ou a Escola é fadada mesmo?' [...] eu acho que é nesse caos, nesses questionamentos diários que eu vou provocando a minha prática, que eu vou fazendo com que essa prática tome um novo rumo" (Luana, 2016).
} 
Luana realiza aí questionamentos fundamentais, buscando se desvencilhar de lógicas estruturantes. A escola é possível ou está fadada ao fracasso, como há muito se diz? Sua doutrina reservada aos animais gregários e domésticos permite a experimentação do docente como singularidade ou necessariamente engessa seus modos de agir?

“[...] eu não consigo achar que ser professor é diferente de fazer uma música, achar que é diferente de pintar um quadro, de fazer uma costura [...] é uma construção, é um costuramento né, é um alinhave que a gente 'tá' o tempo todo fazendo" (Marina, 2016).

Esse "costuramento" do qual Marina trata é puramente subjetivo, na medida em que se coloca nesse cenário apresentando-se como totalidade, em seus medos, suas angústias, suas perdas, suas descobertas. Apresenta-se inteira diante de seu exercício profissional, mesclando ele com dúvidas, desafios e problematizações. A fluidez que se tocam as linhas nos põe a refletir sobre sua dança, seu existir entrelaçado.

“[...] a primeira coisa que eu fiz quando cheguei logo na escola foi: 'vou ler os Estatutos, quais são os meus direitos e os meus deveres' e [...] pela lei né, pelo MEC, pela lei maior da Educação, o que é que tem que fazer [...]. Então, é burlar entre aspas, eu 'tô' fazendo, eu 'tô' tomando outros caminhos, mais resguardada pela lei...então, eu tento fazer o meu diferente, mas amparada [...] eu posso ser a estranha dentro daquela Instituição, mas eu estou cumprindo o que os Estatutos me pedem, entendeu? Então, esse jogo é o tempo todo, as vezes a cobrança é a mais dura possível dentro de uma Instituição, cada vez mais né [...] eu não acho legal você estar em uma escola o tempo todo no combate porque você fica diferente e as coisas começam a endurecer, engessar, mas eu também não acho que eu deva recuar. Então, eu vou o tempo todo fazendo esse trabalho de formiguinha, entendeu? [...] eu não tenho a pretensão de mudar, de achar que 'ah, vou revolucionar a Educação' [...] a gente no pequenininho, no miudinho, eu sempre falo, eu entro na minha sala e aí no caso, os Estatutos, a lei, garante que dentro da minha sala eu sou dona dela [...] na minha sala de aula eu tipo, fecho a porta e dou o que eu quiser, se eu for responsável, se eu tiver dignamente responsabilidade com aquilo que eu estou partilhando, eu faço" (Marina, 2016).

'Não dá 'pra' mudar muito, né. Eu tento mudar dentro da minha sala de aula, no meu cotidiano didático pedagógico eu tento mostrar 'pros' alunos que não é bem isso, né. Assim, que a gente precisa ser mais livre diante de todo esse processo, né. Mas é bem difícil, bem difícil lidar com essas limitações" (Luana, 2016).

Os depoimentos citados nos auxiliam a pensar os movimentos de resistência exercidos pela docência em seu cotidiano. Operando sob vias molares, institucionalizadas, regidas por amplos regulamentos que engessam de várias maneiras a experimentação, Marina nos conta acerca de suas produções desviantes, onde desprezada pelo rebanho, está ciente da posição em que se encontra, mas sem recuo faz seu "trabalho de formiguinha" acontecer. 
Os deslocamentos de força passiva e ativa nesses retratos nos instigam a pensar os movimentos realizados cotidianamente, nesse "jogo/combate" que o docente trava com sua realidade laboral. Procuram dialogar, portanto, com esses entrecruzamentos de linhas em suas experiências diárias possuindo suas salas de aula, desenvolvendo táticas de batalha e resguardando suas práticas enquanto regida por essas leis. As tentativas de (des)territorialização remetem às novas buscas, aos novos encontros, às novas fugas que são criadas a partir da atitude ética que resolvem adotar como docentes, na constante imposição de desafios e resistência ao que já está instituído. As subversões realizadas nesse processo coletivo de forças restauram na educação a possibilidade de ser veículo de desagregação de si mesma.

"Então, teria que ser totalmente diferenciado, teria que ser outros tempos, se de fato se quisesse ensinar na 'EJA', se de fato quisesse pensar em aprendizado na 'EJA'. Mas o que eu percebo muitas vezes é que são números a cumprir né, metas a cumprir, pessoas que foram alfabetizadas, pessoas que elevaram o nível de escolarização em números, mas não na realidade, né" (Inês, 2016).

"[...] acredito que seria uma educação integral, seria assim, que trouxesse muito a formação cidadã, a formação política que hoje a Escola não traz né, aliado a uma prática, né" (Inês, 2016).

"[...] penso que agregaria muito mais no processo, mas eu não tenho muito... eu tenho que ficar buscando, pesquisando e aí vai muito da dinâmica e do tempo do professor, que não é o tempo que ele gostaria. Porque quem se forma tem uma perspectiva de salário né, quer agregar. Mas na verdade o professor tem que ter dois, três vínculos né, para poder ter um salário compatível com o que estudou e aí o seu tempo de pesquisar, o seu tempo de planejar fica muito prejudicado também" (Inês, 2016).

Junto ao estabelecimento da realidade como limite, permite-se, nesse mesmo instante, olhar na direção do vir a ser - do teria que ser - do que poderia ser real, das transformações, dos acontecimentos (da vontade de potência). A realidade, portanto, é sempre mais ou menos do que imaginamos ou suportamos...a realidade é um campo potencial. Partindo desse olhar, a docente consegue ainda vislumbrar ideias próprias de uma educação integral que englobe aspectos éticos, estéticos e políticos. O estabelecimento do finito-ilimitado pressupõe um exercício de máxima potência dos processos de saber, poder e subjetivação. Ao contrário do que usualmente se conclama acerca de uma "liberdade total" para o estabelecimento da criação, observamos que a partir do momento em que se entende a finitude de um campo, seus limites e limitações, sou necessariamente compelido a inventar. Sem necessariamente existir uma batalha contra a oscilação "molaridade-molecularidade", lança-se, por consequência, o indivíduo na direção da criação de novos complexos de subjetivação, novas territorialidades, para recompor sua corporeidade, ressingularizando.

Ainda partindo de suas buscas, expectativas e vontades de realização, depara-se com os limites do mundo, do capitalismo, do cotidiano, do consumo, das necessidades humanas. Junto ao "ímpeto de um rítmico mutante" (GUATTARI, 1987, p. 9) do movimento molar- 
-molecular, novamente coloca-se como sujeito dentro de um plano de consistência. Corre-se sempre o risco de se (re)territorializar, de se molarizar em antigas máquinas de controle e submissão. Nesse sentido, é necessário estar atento às tentativas (re)territorializadoras conservadoras, que operam por serialidade e não por singularização.

\footnotetext{
"Qual foi a função do professor se não levar esse novo conhecimento para agregar ao conhecimento dele? O professor, ele passou por um processo, ele se preparou...então, eu acredito que ele transmite sim e que ele recebe sim o conhecimento; $[\ldots]$ muitas vezes ele vai com uma proposta, né. E quando ele observa que não atingiu o objetivo dele, ele está aprendendo também que ele precisa reelaborar isso" (Inês, 2016).
}

\begin{abstract}
"Ser professor é você oferecer coisas, coisas que emocionem...e não é essa emoção piegas, $[\ldots]$ mas uma coisa mesmo que te tome. Então, a gente tem muito a conhecer porque o conhecimento é partilha 'pra' mim, o conhecimento é partilhar..." (Marina, 2016).
\end{abstract}

Esses deslocamentos provocados pela prática docente não se configuram apenas nos sujeitos que realizam a ação. Aqui, as entrevistadas dialogam com o principal receptor de seu ofício: o aluno. Inês se vê, enquanto força subjetivadora, disruptora, produtora de deslocamentos também nesses alunos evocando o conhecimento que adquiriu em sua formação e experiência como fonte de transformação da realidade. A "reelaboração" a que se refere denota a necessidade de processos de atividade molecular e de fuga, de reflexão, de invenção, de ruptura, mesmo em um plano limitado que já conhece e convive. Esse "processo" pelo qual o professor passou, aqui se refere à diferença estabelecida entre sua vida e a de outra pessoa, entre a sua experiência dotada de substancialidade, que a subjetiva a cada momento. Já Marina resgata a concepção de partilha, de troca, de recepção e devolução, de emoção, de arrebatamento pelo conhecer. Ambas as concepções acerca do significado e do sentido de "ser professor" parecem navegar por lógicas próprias de produção da docência vislumbrando objetivos e possibilidades muito singulares.

\title{
CONSIDERAÇõES FINAIS
}

Por meio da análise das linhas cartográficas (molares, moleculares, de fuga), que circundam e se entrelaçam nos discursos de Inês, Luana e Marina, foi possível configurar um mapa dos jogos simbólicos e práticos que se fazem presentes na profissão docente. Os temas foram sendo costurados junto aos relatos e perpassaram várias esferas do cotidiano docente: aperfeiçoamento ao mercado de trabalho, a noção de autoridade, formação serializada, gênero, discursos demagógicos, valores religiosos, violência enquanto força exercida, as esferas do público e do privado, entre outros. Concomitantemente, delinearam-se propostas subjetivas importantes para compreender uma dinâmica microestética que se 
exerce e se apresenta. A docência parece se inserir também como produção de diferença, construção subjetiva que se realiza cotidianamente, tem forma plástica e é maleável.

Buscou-se, nesse contexto, utilizar concepções estéticas que se ligam à filosofia nietzschiana: as três transmutações do espírito. Por intermédio da cartografia, contrapomos a lógica metodológica habitual, priorizando necessariamente o caminho da pesquisa, sua processualidade. O plano imanente, onde tudo se encontra materializado no acontecimento, contraria também a relação transcendental privilegiada pelo pensamento metafísico tradicional. É possível, portanto, desconstruir mitos que se encontram intrinsecamente presentes nas noções metodológicas Ocidentais, como o da neutralidade e o da objetividade científica.

Corroborando com a ideia de uma desconstrução da experiência docente, opõe-se a concepção do professor-profeta à perspectiva de um professor-militante. Essa militância estaria instaurada em um tipo docente que vivencia as misérias de seu público e partindo dessa vivência constrói e produz coletivamente novas possibilidades existenciais. Não se trata de negar o lugar em que se insere, sendo essas misérias não apenas econômicas, mas sociais, culturais, intelectuais. Dentro dessas dificuldades, esse docente desenvolve "células de luta", escapes do controle, formas de desvio, como uma produção cotidiana do presente, não apenas anunciando o novo, mas o produzindo. A essa compreensão, une-se a concepção de uma microestética, uma "educação menor" enquanto dispositivo de funcionamento coletivo que aposta na multiplicidade, sem priorizar a delimitação de verdades (GALLO, 2012).

Concluímos que, apenas por meio da superação do plano moral instaurado no pensamento ocidental, desconstruindo os pressupostos universalmente dominantes e optando por uma ética ativa que visa o desenvolvimento de novos sentidos e novos valores humanos, poderíamos pensar a vida em suas dimensões caóticas, de movimento e tragicidade. Apenas rejeitando os moldes binários previamente estabelecidos e percebendo a vida como única possibilidade de julgamento sob ela mesma, poderíamos relativizar as problemáticas das instituições modernas ocidentais, buscando mover suas rígidas bases. Esse reposicionamento exige, portanto, o reconhecimento da necessidade de desenvolver o potencial subjetivo, microestético, introvertido da docência, para compor um professorar cada vez mais ativo, transformador, que incite e estimule a diferença.

\section{REFERÊNCIAS}

- Luana. Entrevista I. Aracaju/SE - Brasil, setembro, 2016.

- Inês, 53 anos. Entrevista II. Aracaju/SE - Brasil, setembro, 2016.

-Marina, 51 anos. Entrevista III. Aracaju/SE - Brasil, outubro, 2016.

DELEUZE, Gilles; GUATTARI, Félix. Mil Platôs: capitalismo e esquizofrenia. Trad. Aurélio Guerra Neto, Ana Lúcia de Oliveira, Lúcia Cláudia e Suely Rolnik. São Paulo: Edito- 
ra: 34, 1996. Vol. 3 (Coleção Trans).

GALLO, Silvio. Em torno de uma educação menor. Revista Educação e Realidade, 27 (2): 169-178 jul./dez. 2002.

GROPPA, Júlio. A violência escolar e a crise da autoridade docente. Cadernos Cedes, ano XIX, $\mathrm{n}^{\circ}$. 47, dezembro/98. Disponível em: <http://docslide.com.br/documents/aquino-julio-groppa-1998-a-violencia-escolar-e-a-crise-da-autoridade-docente.html $>$ Acesso em: 24/11/2016.

GUATTARI, Félix. Revolução Molecular: pulsações políticas do desejo. Trad. Suely Rolnick, 3. ed. São Paulo: Editora Brasiliense, 1987.

LOURO, Guacira Lopes. Mulheres na sala de aula. In: DEL PRIORE, Mary. (Org). A história das mulheres no Brasil. São Paulo: Editora Contexto, 2008, p. 443-481.

NIETZSCHE, Friedrich. Assim falou Zaratustra: um livro para todos e para ninguém. Trad. Paulo César de Souza. São Paulo: Companhia das Letras, 2011.

NIETZSCHE, Friedrich. Genealogia da Moral: uma polêmica. Trad. Paulo César de Souza. São Paulo: Companhia das Letras, 1998.

PEREIRA, Marcos Vilella. Estética da professoralidade: um estudo crítico sobre a formação do professor. Santa Maria: Editora UFSM, 2013.

RANCIÈRE, Jacques. O mestre ignorante. Cinco lições sobre a emancipação intelectual. Trad. Lílian do Valle. Belo Horizonte: Editora Autêntica, 2002.

ZOURABICHVILI, Francois. O vocabulário de Deleuze. Trad. André Telles. Rio de Janeiro, Ifch- Unicamp, 2004. Disponível em: < http://escolanomade.org/wp-content/downloads/deleuze-vocabulario-francois-zourabichvili.pdf $\geq$ Acesso em: 10/12/2016.

Artigo baseado na dissertação de mestrado da pesquisadora: "O professorar estético: niilismo e educação" - Universidade Tiradentes, 2017.

Este trabalho foi aprovado pelo Comitê de Ética da Pós-Graduação de Pesquisa da Universidade Tiradentes/SE em 01/09/2016. Os nomes foram substituídos para preservar a identidade das docentes. 


\section{Dados dos autores}

\section{Juliana Monteiro Vieira}

Doutoranda em Educação pelo Programa de Pós-graduação da Universidade Federal de Sergipe (PPGED/UFS), Mestre em Educação pelo Programa de Pós-graduação em Educação da Universidade Tiradentes/SE (PPED/Unit - 2017); Graduada em Psicologia pela Universidade Tiradentes/SE (2014); Participante e colaboradora dos grupos GPHEN/CNPQ (UNIT/SE) e GPECS/CNPQ (UFS/SE). Bolsista de Doutorado da FAPITEC/SE. E-mail: juhsantosvieira@gmail.com

\section{Cristiano Ferronato}

Doutor em Educação pela Universidade Federal da Paraíba (2012); Mestre em Educação pela Universidade Federal da Paraíba (2006); Graduado em História pela Universidade Estadual de Maringá (2003); Professor e Pesquisador do Programa de Pós-Graduação em Educação da Universidade Tiradentes, PPED-UNIT; Líder do GPHEN/CNPQ-SE. E-mail: cristianoferronato@gmail.com

\section{Dinamara Garcia Feldens}

Pós-doutora (UCM-Madrid); Doutora em Educação - UNISINOS (2004); Mestre em Educação - UNISINOS (1999); Graduada em História (1996); Pesquisadora e líder do GPECS/ CNPQ. Professora do Departamento de Educação e do Programa de Pós-Graduação em Educação da Universidade Federal de Sergipe (PPGED/UFS). E-mail: dfeldens@,hotmail. $\underline{\text { com }}$

Submetido em: 31-7-2017

Aceito em: 7-2-2018 